\title{
CONSTITUIÇÕES BRASILEIRAS, LEGISLAÇÄO E TERRAS DEVOLUTAS
}

\author{
Odah Regina Guimarães Costa*
}

\section{Introdução}

O Estado, uma realidade indiscutível, transcende os elementos que lhe são sensíveis, como território, população, corpo de regras obrigatórias.

Suporte do poder político, independente de posicionamentos e opiniões sobre a sua tipologia, o Estado pode ser distinguido, segundo alguns autores, como: Estado-comunidade e Estado-poder; como sociedade, no sentido de que os cidadãos fazem parte deie para a concretização de fins comuns, e, como poder político, expresso pela atuação de órgãos, serviços e ação de autoridade. ${ }^{1}$

Além dos elementos de ordem histórica, geográfica, econômica, política, social e moral há o elemento jurídico, que estabelece relações entre dirigentes e dirjgidos, expresso por direitos e deveres, por disposições e vinculações. Cabe, em princípio, aos governantes o direito de governar e aos governados o dever de obedecer. O poder fundamenta-se numa idéia de Direito e a autoridade dos governantes deve ser uma autoridade constituída - prevista na Constituição. ${ }^{2}$

Estadọ e instituições são regulamentadas pelo Direito e regem-se segundo regras jurídicas. É o Direito Constitucional que regulamenta

$$
\begin{aligned}
& \text { o próprio Estado enquanto comunidade e enquanto } \\
& \text { poder. }^{3}
\end{aligned}
$$

As revoluções burguesas do século XVIII e XIX derrubaram o Estado absolutista e culminsiam com a implantação do Estado constitucional, regido por uma Constituição, que pode ter as ca-

- Professora Titular, Livre-Docente, Doutora do Departamento de História da Universidade Federal do Paraná e Bacharel em Direito.

1) MIRANDA, Jorge. Manual de direito constitucional; preliminares à experiência constitucional. 3. ed. rev. Coimbra, Coimbra Ed. 1985, p. 13-4.

2) - p. 14.

3) - p. 15. 
racterísticas de uma Constituição política como de uma Constituição social. ${ }^{4}$

O Estado constitucional, caracteristicamente liberal e burguês no século XIX, expressão de concepção de vida e mentalidade burguesa, assistiu à afirmação das liberdades jurídicas individuais e da liberdade de contrato.

O liberalismo, filosofia global, tendo como centro a França, expande-se por toda a Europa, influindo decisivamente no movimento independizante da América. Vê constituírem-se, mesclado com o nacionalismo, os modernos Estados nacionais da Itália, Alemanha e países balcânicos.

Surgem posicionamentos doutrinários contrários à filosofia do liberalismo, incluindo reacionários (Joseph de Maistre, De Bonald), defensores dos princípios da Igreja (do Syllabus à Rerum Novarum) e socialistas, passando do socialismo utópico ao socialismo científico (Saint-Simon, Owen, Fourier, Proudhon, Marx e Engels).

As críticas, principalmente aquelas feitas por Marx e Engels, trouxeram transformações no liberalismo, contribuindo para a abolição da escravatura, o desenriolvimento do Direito e do processc penal, a liberdade de imprensa e outras e, de modo indireto, na auto-gerência do Direito, que passa a atender mais diretamente as reivindicações e necessidades da sociedade, expressas, em especial, pela liberdade sindical e pelo sufrágio universal.

Distinções devem ser feitas em relação ao Estado de classe e o Estado liberal segundo alguns autores, como Georges Burdeau. ${ }^{5}$ Segundo ele, o Estado de classe caracteriza-se pela subordinaçâo da sociedade ao Estado. O poder é exercido por uma classe dominante, que comanda toda a coletividade. Impõe-se um regime político autoritário, no sentido de corrigir e nivelar as diferenciações sociais. Por outro lado, o Estado liberal fundamenta-se na autonomia que goza a sociedade face ao Estado. Continuando, o referido autor confirma que

Não é o Poder que impõe uma estrutura à sociedade, é ela que, espontaneamente, segrega a sua ordem que o poder tem apenas por missão garantir. A iniciativa é social e não política. ${ }^{6}$

Dentro desta ótica, é a sociedade que cria a sua própria estrutura, que a regulamenta, que a ordena, cabendo ao poder a sua garantia.

4) HAURIOU, Maurice. Précis de droit constitutionnel. 2. ed. Paris, 1929, p. 611 e segs. Citado por MIRANDA, p. 17.

5) BURDEAU, Georges. O Estado. Lisboa, Europa - América, s. d. p. 132.

6) p. 132. 
Um terceiro posicionamento é dado pelas democracias ocidentais contemporâneas, baseado na tradição liberal e representado pela democracia pluralista, que

faz da colectividade inteira, na sua autenticidade sociológica, a base do Poder estatal. ${ }^{7}$

A democracia pluralista, baseada nas solidariedades que a complexa vida moderna articula, principalmente no plano econômico, entre as diversas categorias sociais, busca soluções muito mais num plano técnico do que espiritual, sofrendo críticas violentas no que se refere à sua eficária. ${ }^{\mathrm{s}}$

Outras formas de Estado ciesenvolvem-se nos países do 'Terceiro Mundo, que conquistaram a sua independência política após a Segunda Guerra Mundial. A descolonização contribuiu para a formação de novos Estados, regidos por princípios liberais-democráticos, socialistas, ou sob uma forma de não-comprometimento e de auto-determinação dos seus destinos.

A existência da comunidade internacional e a criação de írgãos supra-nacionais, como a ONU, que zela pela paz mundial e pelos direitos do homem, trouxeram novas perspectivas para o futuro da humanidade.

Direitos econômicos, sociais e culturais, ao mesmo tempo que se universalizam, guardam seus aspectos garantias individuais, incluindo a forma de sufrágio universal, a existência legal dos partidos de massas, a superação de regimes monárquicos por regimes republicanos, a divulgação das Constituições, a diversificação dos fins do Estado, a maior participação dos grupos sociais no cenário político, o prestigiamento da função administrativa, a afirmação do poder executivo, em prejuízo do Farlamento. ${ }^{9}$

O Brasil, no qual o Estado vem passando por significativas transformações, ajusta-se, nos cias atuais, aos moldes de uma democracia pluralista, ou está criando um sistema próprio, fruto das contingências conjunturais?

\section{Constituições Brasileiras e o Direito da Propriedade}

Para abordar o assunto, colocam-se alguns problemas básicos, assim enunciados:

1. Em que medida a análise do discurso antropológico das Constituições brasileiras, principalmente no que se refere à posse e à propriedade, e da legislação de terras, decorrente do processo de colonização implantado por Portugal no Brasil, permite
7) - p. 144.
8) $144-7$.
9) MIRANDA, p. 85-6. 
detectar o direcionamento e a tentativa de solução de problemas fundamentais, como o das terras devolutas?

2. De que modo as Constituições e a legislação de terras retratam o ambiente político, social, econômico e cultural em que foram geradas e qual a correspondência dos textos com as idéias e as aspirações dominantes na época, em relação às elites dirigentes e aos outros componentes da sociedade?

3. Em que medida, com a abertura do processo político da nação, esboçam-se tentativas para a solução de alguns problemas estruturais, objetivando, inclusive, a concretização de uma reformá agrária no sentido de atender aos anseios de significativo contingente da população brasileira?

A análise vai ser feita dentro do contexto global.

A Constituição, ou Carta Magna, é a fonte da qual dimana a ação governamental, regulando a vida política, social, econômica e cultural de uma nação, podendo ser definida da seguinte forma:

Uma Constituição é, precisamente, a forma de organização especificamente política das sociedades economicamente complexas. ${ }^{10}$

É uma definição objetiva, c’ara, no seu sentido genérico, destacando-se o seu caráter político e social, podendo incluir, a nosso ver, a expressão "sociedades economicamente organizadas", em vez do que foi enunciado, porque nem todas as economias são necessariamente complexas.

Constata-se, na essência do contexto político-ideológico do Brasil, que se tornou independente em 1822, a mudança, a transformação, expressa por sucessivas Constituições.

No decorrer da sua História, o povo brasileiro teve que aceitar duas Constituições outorgadas, uma terceira votada por um Congresso cerceado em seus direitos, e quatro aprovadas em Assembléias Constituintes, incluindo a atual.

As Constituições, leis básicas do país, nasceram como fruto das próprias condições conjunturais e do espírito da época em que foram elaboradas, correspondendo, inclusive, à expressão do poder da classe dominante. Somente com a evolução do processo político é que os demais grupos da sociedade vão garantindo a sua participação, haja vista a. convocação do povo brasileiro para tomar parte na organização da atual Constituição do Brasil.

10) ALMEIDA, Paulo Roberto de. Uma interpretação econômica da Constituição Brasileira (a representação dos interesses sociais em 1946 e em 1986). Ciência e Cultura, 39 (1): 35, jan. 1987. 
A intelligentsia brasileira foi inicialmente moldada nos modelos intelectuais portugueses. A partir do século XVIII, a França assume a dianteira no plano cultural e na preferência dos brasileiros, que procuram aderir às idéias francesas, cheias de espírito revolucionário e inovador. O contato fazia-se principalmente através de brasileiros que estudavam na Europa e da divulgação das icéias em livros, folhetos e outros meios de divulgação.

As idéias do liberalismo econômico, surgido com a Fisiocracia e depois com a Escola Clássica da Inglaterra, arregimentaram adeptos na sociedade da época.

A Constituição Política do Império do Brasil, de 25 de março de $1824,{ }^{11}$ calcada em projeto de Antonio Carlos e reorganizada pelo Conselho de Estado, foi influenciada pela Carta Francesa de 1814, que marcou a Restauração com Luis XVIII, e, indiretamente, pelo Direito inglês. Criou o Eștado monárquico liberal e foi outorgada por D. Pedro I, que dissolvera a Assembléia, juntando, aos três poderes clássicos, o poder moderador, da competência do Imperador. Foi uma imposição da. sua vontade à nação.

A Independência política do Brasil (1822) não significou a realização de um ideal do povo brasileiro. Resultou de uma série de circunstâncias, influenciadas pela presença da corte real portuguesa no Brasil e pelo movimento constitucional em Portugal, que haveriam de criar condições para o estabelecimento de um principe português no trono do Brasil.

Caio Prado Júnior analisa a situação que envolveu a Independência do Brasil, quando diz:

Fêz-se a Independência pràticamente à revelia do povo; e se isto lhe poupou sacrifícios, também afastou por completo sua participação na nova ordem política. A Independência brasileira é fruto mais de uma classe que da nação tomada em conjunto. ${ }^{12}$

O exercício do poder pelos grupos sociais da época é evidenciado por João Cruz Costa, quando afirma que:

Na ausência de participação do povo nesse momento, a classe que assumiu o poder foi ainda a dos ricos proprie-

11) BRASIL. Constituição. Constituição política do Império do Brasil de 25 de março de 1824. In: —_ Constituições do Brasil (de 1824, 1891, 1934, 1937, 1946 e 1967 e suas alterações). Brasilia, Senado Federal, 1986, v. 1, p. 13-35.

12) PRADO JÚNIOR, Caio. Evolução política do Brasil. São Paulo, Brasiliense, 1953, p. 50 . 
tários de terras e de engenhos, a herdeira dos letrados do século XVII. São essas classes superiores, constituídas de bacharéis eruditos e de ricos proprietários de engenho, que conduzirão o Brasil na fase imperial. ${ }^{13}$

Dessa forma, a Constituição Imperial veio garantir os direitos de uma classe dirigente, não se preocupando com a situação dos outros grupos que compunham a sociedade.

O romantismo, movimento filosófico, religioso, social e cultural marcante no início do século XIX, também influenciou o pensamento brasileiro da época, insinuando-se inclusive um ecletismo, que conseguiria selecionado grupo de adéptos.

A monarquia liberal no Brasil fundamentou-se no constitucionalismo como ume, forma de garantir o progresso, salvaguardar os seus interesses, abrindo-se perspectivas para a democracia burguesa, porém, com o exercício do poder pela burguesia territorial.

Em síntese, a Constituição de 1824 veio atender aos interesses dos grandes proprietários de terras, latifundiários e escravocratas, adeptos das idéias liberais porque elas aında não ameaçavam o seu poder. Consagrava a autoridade do Imperador e resguardava, para os que detinham o poder econômico e social, representado pela posse e propriedade da terra, a gerência das empresas produtoras da época, o controle do capital e da mão-de-obra, deixando de atender aos reclamos da maioria da população.

No que se refere à propriedade, a Constituição Imperial coloca-a num plano ideal, garantindo o aireito a ela, sem criar mecanismos para a sua aplicação. O art. 179, § 22 estabelece:

Art. 179 - A inviolahilidade dos direitos civis e politicos dos cidadãos brasileiros, que tem por base a liberdade, a segurança individual e a propriedade, é garantida pela Constituiçãc do Império, pela maneira seguinte:

22) É garantido o direito de propriedade em toda a sua plenitude. Se o bem público, legalmente verificado, exigir o uso e emprego da propriedade do cidadão, será ele previamente indenizado do valor dela. A lei marcará os casos com que terá lugar esta única exceção e dará its regras para se determinar a indenização. ${ }^{14}$

A Constituição do Império apresentava a propriedade como um direito pleno, garantido pela ordem pública, sem caracterizar

13) COSTA, João Cruz. Contribuição à história das idéias no Brasil. Rio de Janeiro, J. Olympio, 1956, p. 79.,

14) BRASIL; Constituições ... v. 1, p. 32-4. 
a propriedade-função, integrada ao sistema capitalista de produção. Prevê a indenização, no caso de uso e utilização da propriedade, a bem público, na proporção do seu valor, sendo da competência da lei a determinação dos casos de exceção e das regras de execução.

Este dispositivo constitucional consta das outras Constituições com algumas modificações na redação e itens complementares, mas o espírito permanece o mesmo.

O Ato Adicional de 1834, implantado pela lei n. ${ }^{\circ} 16$, de 12 de agosto de $1834,,^{15}$ que veio alterar a Constituição de 1824, decretou mudanças e estabeleceu algumas adições, não expressando todas as aspirações das correntes liberais.

A lei n. ${ }^{0}$ 105, de 12 de maio de $1840,{ }^{16}$ interpreta alguns artigos da reforma constituciona!, restringe algumas concessões feitas às Assembléias de Província e corrige excessos federalistas. As modificaçõcs não param por aí. A lei n. ${ }^{2}$ 234, de 23 de novembro de $1841,{ }^{17}$ cria um Conselho de Estado, estabelecendo a sua composição, sob a presidência. do Imperador, as suas responsabilidades e incumbências. As forças liberais são superadas pelas conservadoras, com alternância no poder em todo o período imperial, não conseguindo conter as atitudes de insatisfação e oposição social, que criariam um clima favorável à implantação do regime republicano.

As transformações estruturais que se deram no decorrer do século XIX coincidiram com nova fase na estrutura jurídica brasileira, que passa a se caracterizar por uma mentalidade com cunho acentuadamente nacionalista, inspirada em modelos vigentes na época, principalmente franceses. é representada por diversos Códigos e por leis de alta significação jurídica e histórica, como o Código Criminal de 1830, elaborado por Bernardo Pereira de Vasconcellos, o Código de Processo Criminal, organizado por Manoel Alves Branco, segundo Visconde de Caravelas, o Código Comercial originado de projeto de 1833, dos comerciantes José Antonio Lisboa, Inacio Ratton, Lourenço Westin e Guilherme Midosi, aprovado em 1835, persistindo o desafio da elaboração de um Código Civil.

O jurisconsulto Augusto Teixeira de Freitas, a principal expressão da cultura jurídica do país na época, elaborou, por con-

15) Lei n. 16, de 12 de agosto de 1834 (ato adicional). In: BRASIL, Constituiçōes ...v. 1, p. 49-53.

16) Lei n. 105 , de 12 de maio de 1840. In: BRASIL, Constituições ..., v. 1, p. 55-6.

17) Lei n. 234 , de 23 de novembro de 1841. In: BRASIL. Constituiçōes ..., v. 1, p. 57-8. 
trato com o Governo, a Consolidação das Leis Civis (1857) e o Esboço (2 tomos em 3 volumes), propondo a alteração dos planos e a unificação do Direito Privado, com aprovação do Conselho de Estado, mas com rescisão do contrato pelo ministério.

Ainda outras tentativas se fizeram, incluindo contrato firmado com o Senador Nabuco de Araujo, truncado em $1878 \mathrm{com}$ o seu falecimento; projeto apresentado, em 1881, por Joaquim Felicio dos Santos, não aprovado, e a constituição de duas comissões, sem que o Império visse publicado o Código Civil, que vai ser uma conquista da República. Em 1916 foi aprovado o projeto de Clóvis Bevilaqua, fiel à tradição e ao estado social do país, traduzido no direito das famílias e no direito das sucessões, em detrimento da questão social.

Transformações se deram no século XIX, caracterizadas pela desagregação das estruturas sócio-econômicas e político-administrativas, culminando com a abolição da escravidão (1888) e a Proclamação da República (1889).

Ressalte-se que não se deu simplesmente a queda da ordem imperial e o estabelecimento da ordem republicana mas uma série de crises haveriam de contribuir para as transformações, como a questão religiosa, a crise militar, a mudança do sistema de trabalho escravo pelo trabalho livre, e entrada de imigrantes e a emergência de novos grupos de dominação. É o que afirma Fernando Henrique Cardoso:

Em síntese, nem a República foi mera quartelada, nem se tratou apenas - como se estas não importassem... de uma mudança ao nível das instituições, que de monárquicas passaram a republicanas, mas houve, de fato, uma mudança nas bises e nas forças sociais que articulavam o sistema de dominação no Brasil. ${ }^{18}$

O movimento, defendido pelas elites pensantes e sob a inspiração do positivismo de Augusto Comte, não se formou na consciência das massas e mesmo entre os seus principais artífices havia posicionamentos discutíveis face à ordem republicana, como Deodoro da Fonseca, que não se manifestara em nenhuma ocasião republicano, e Rui Barbosa, um dos colaboradores da nova carta política, que não era um republicano convicto. D̃a mesma forma, a Constituição da República dos Estados Unidos do Brasil, de 24 de fevereiro de 1981,19 não surgiu como uma respos-

18) CARDOSO, Fernando Henrique. Dos governos militares a Prudente - Campos Sales. In: O Brasil republicano: estrutura de poder e economia (1889-1930). São Paulo, DIFEL, 1975, v. 1, p. 16. (História geral da civilização brasileira). 
ta nacional aos desafios, já que ela se baseou no modelo da Constituição dos Estados Unidos.

cujos principios se transplantaram quase na sua totalidade para o nosso sistema de vida, sem, contudo, sofrerem um processo de adaptação. Mais uma vez fomos buscar fora de nossas fronteiras as idéias e as fórmulas para a solução de uma crise nacional. ${ }^{20}$

Trouxe transformações de ordem político-institucional, implantando o Estado republicano, suprimindo para isso, o poder moderador, separando o Estado da Igreja, instituindo e fortalecendo o federalismo, estabelecendo o regime representativo, com o poder dividido entre o legislativo (bicameral), o executivo, com o Presidente escolhido por eleição, e o judiciário, com juízes do Supremo Tribunal nomeados em caráter vitalício, com cassação do cargo por sentença principal. Criou condições favoráveis para as oligarquias, sem melhorar a situação dos outros segmentos da população.

No que se refere às liberdades individuais, a Constituição de 1891 estabelece disposições no art. 72, que consagram a inviolabilidade dos direitos relativos à liberdade, à segurança individual e à propriedade e, no $\S 17$, firma este princípio:

Art. 72 - A Constituicão assegura a brasileiros e a estrangeiros residentes no País a inviolabilidade dos direitos concernentes à liberdade, à segurança individual e à propriedade, nos terrios seguintes:

$\S 17$ - O direito de propriedade mantém-se em toda a sua plenitude, salva a desapropriação por necessidade ou utilidade pública, mediante indenização prévia.

As minas pertencem aos proprietários do solo, salvas as limitações que forem estabelecidas por lei a bem da exploração deste ramo da indústria..11

Na Constituição de 1891, com emendas de 1926,22 mantém-se o art. $72 \S 17$, no seu caput, desdobrando-se, a seguir, nas letras "a" e "b", como segue:

19) Constituição da República dos Estados Unidos do Brasil de 24 de fevereiro de 1891. In: BRASIL, Constituições .... v. 1, p. 83-107.

20) LUCAS, Fábio. O conteúdo social nas constituições brasileiras. Belo Horizonte, Universidade de Minas Gerais, 1959, p. 56.

21) BRASIL, Constituições ..., art. $72, \S 17$, v. 1, p. 100-1.

22) Emendas de 1926 à Constituição de 1891. In: BRASIL, Constituiçōes .... v. 1, p. 109-32. 
Art. 72

$\S 17$

a) as minas pertencem ao proprietário do solo, salvo as limitações estabelecidas por lei a bem da exploração das mesmas;

b) As minas e jazidas minerais necessárias à segurança e defesa nacionlais e às terras onde existirem não podem ser transferidas a estrangeiros. ${ }^{23}$

O liberalismo constitui a tônica fundamental do documento constitucicnal, garantindo o pleno direito à propriedade e resguardando o caso de desapropriação, mediante indenização. Ressalvam-se os direitos dos proprietários de minas, atendidas as limitações, previstas em lei, estabelecendo-se, nas emendas de 1926, dispositivos no sentido de preservar a segurança e a defesa nacionais e proibir a transferência a estrangeiros.

Quanto à decretação de impostos, a Constituição de 1891 estabelece no art. 9. ${ }^{\circ}, \S 2 .^{\circ}$;

Art. 9. ${ }^{\circ}$ - da competência exclusiva dos Estados decretar impostos:

2. $\left.{ }^{\circ}\right)$ sobre imóveis rurais e urbanos. ${ }^{24}$

A Constituição de 1891, com emendas de 1926, mantém a mesma determinação no art. $9 .^{\circ}, \S 2 .{ }^{0},{ }^{25}$ vigorando o referido princípio nas outras Constituições.

As Constituições de 1824 e 1891 não conseguiram romper os quadros dominantes e nem foram contestadas por um grupo social que oferecesse outra opção definitiva, clara, objetiva. A sociedade da velha República ainda fundamentava-se numa economia de exportação de produtos primários, havendo antagonismos entre proprietários e não proprietários. A estrutura agrária expressava-se pelo campesinato, ou quase campesinato, sem esquecer as formas de coronelismo, a meação, a parceria, o colonato. A burgues:a agrária passaria pcr uma evolução, transformando-se numa o!jgarquia anti-burguesa.

Somente com a afirmação das novas lideranças e o incentivo da lavoura, a aplicação de capitais para a dinamização da industria'ização, o crescimento demográfico e o desenvolvimento da urbanizaçáo é que se criariam condições para transformações mais profundas nas estruturas.

23) Art. $72, \S 17$, a e b. v. 1, p. 127-8.

24) BRASIL, Constituições .... art. $9 .^{\circ} \S 2 .^{\circ}$, v. 1, p. 88

25) Emendas de 1926 à Constituição de 1891. In: BRASIL, Constituiçōes art. 9. § 2. v. 1, p. 115. 
As contingências nacionais e mundiais levam o Estado a aplicar uma política intervencionista para enfrentar e superar os problemas surgidos com a crise de 1929 e a grande depressão de 1932. A revolução de 1930, que culminou com a tomada do poder por Getúlio Vargas, veio rornper com a ordem oligárquica estabelecida, procurando aumentar o poder da União e do executivo, estabelecendo campo favorável para um governo forte na base dos decretos-leis.

Começa a mudar a mentalidade de um Brasil arcaico, tradicional, sob o influxo de um espírito inovador, que se firma a partir de 1930, fruto das contingências nacionais e internacionais, marcadas pela crise do sistema capitalista.

A Constituição de 16 de julho de 1934, ${ }^{26}$ inspirada na Constituição de Weimar, com algumas emendas de 18 de dezembro de 1935, reforça o poder do Estado em todos os setores da vida nacional, adotando posição mais contida no que se refere ao sistema liberal e atuando mais diretamente no processo econômico, no sentido de atender ao bem social. Trata da Organização Federal e amplia as atribuições dos três poderes, especialmente o poder executivo.

A filosofia da Constituição de 1934 está condensada no seu preâmbulo:

Nós, os representantes do povo brasileiro, pondo a nossa confiança em Deus, reunidos em Assembléia Nacional Constituinte para organizar um regime democrático, que assegure à Nação a unidade, a liberdade, a justiça e o bem-estar social e econômico, decretamos e promulgamos a seguinte Corsstituição da República dos Estados Unidos do Brasil. ${ }^{27}$

O objetivo fundamental era resguardar a democracia e organizar a ordem econômica e social, de forma que o setor privado não anulasse os direitos individuais garantidos pela Constituição e que fosse possível, aos que vivem do trabalho, participando para o desenvolvimento desse poder, ter uma situação condizente com os ideais da justiça social vigentes no mundo ocidental e numa sociedade em fase de desenvolvimento. ${ }^{28}$

26) Constituição da república dos Estados Unidos do Brasil de 16 de julho de 1934. In: BRASIL, Constituições ..., v. 1, p. 137-88.

27) BRASIL, Constituições ..., p. 141.

28) GUSMÃO, Paulo Dourado. Manual de direito constitucional. Rio de Janeiro, Freitas Bastos, 1957, p. 234. 
No que tange ao direito à propriedade, o art. $113, \S 17$, consagra o referido direito, defendendo, inclusive, os direitos à liberdade, à subsistência, à segurança individual e, na sua essência, o interesse social, ou coletivo, prescrevendo também a despropriação, como segue:

Art. 113 - A Constituição assegura a brasileiros e a estrangeiros residentes no País a inviolabilidade dos direitos concernentes à liberdade, à subsistência, à segurança individual e à propriedade, nos termos seguintes:

17) $\mathrm{E}$ garantido o direito de propriedade, que não poderá ser exercido contra o interesse social ou coletivo, na forma que a lei determinar. A desapropriação por necessidade ou utilidade pública far-se-á nos termos da lei, mediante prévia e justa indenização. Em caso de perigo iminente, como guerra ou comoção intestina, poderão as autoridades competentes usar da propriedade particular até onde $o$ bem público o exija, ressalvado o direito à indenização ultexior. ${ }^{29}$

Transcendendo ao discurso, a Constituição de 1934, caracteriza-se por ser liberal, preocupada com o interesse social, ou coletivo, tendendo para o Fascismo, democrática, com forte influência da doutrina social da Igreja, aberta para a fundamentação de uma legislação trabalhista, preocupada com problemas de guerra, ou de comoção interna. Não implantou uma reforma estrutural mas consagrou alguns princípios socializantes, contribuindo para algumas transformações na sociedade e na economia. Ativam-se os elementos desagregadores da estrutura latifundiária e da produção de produtos primários destinados à exportação, articulam-se as bases para o take-off da industrialização brasileira e arregimentam-se as forças sociais, que, no dizer de Nelson Werneck Sodré, ${ }^{30}$ seriam capazes de deflagrar a. Revolução Brasileira.

A Constituição de 1934 trata do problema agrário, dando-lhe melhor regulamentação que a de 1891. Prescreve a taxação de impostos pelos Estados da seguinte forma:

Art. 8.0 - Também compete privativamente aos Estados: I - decretar impostos sobre:

29) BRASIL, Constituições ...., art. 113, § 17, v. 1, p. 169-70.

30) SODRÉ, Nelson Werneck. Introdução à revolução brasileira. Rio de Janeiro, J. Olympio, 1958, p. 51-2. 
a) propriedade territorial, exceto a urbana. ${ }^{31}$

O Título IV Da Ordem Econômica e Social prevê, no art. 125,32 o domínio do solo por ocupação, poì um não proprietário, por dez anos contínuos com sentença gratuita, como segue, com confirmação no art. 148, da Constituição de $1937,{ }^{33}$ firmando-se a figura jurídica do domínio do solo:

Art. 125 - Tođo brasileiro que, não sendo proprietário rural ou urbano, oclipar, por dez anos contínuos, sem oposição, nem reconhecimento de domínio alheio, um trecho de terra até de': hectares, tornando-o produtivo por seu trabalho e tendo nele a sua morada, adquirirá o domínio do solo, mediante sentença declaratória devidamente transcrita. ${ }^{34}$

A Constituição de 1934 prescreve, no art. 130, que:

Art. 130 - Nenhuma concessão de terras de superfície superior a dez mil hectares poderá ser feita sem que, para cada caso, preceda autorização do Senado Federal. ${ }^{35}$

A referida disposição constitucional expressa a política que vinha sendo aplicada na concessão de áreas com mais de dez mil hectares cabendo ao Senado Federal, opinar sobre a respectiva concessão, dependendo, em última análise, da decisão do poder executivo, que dominava o legislativo, expressando o clima político do país, voltado também para um nacionalismo crescente, face à grave crise mundial que se manifestaria em 1939.

A Constituição dos Estados Unidos do Brasil de 10 de novembro de $1937^{36}$ concedida por Getúlio Vargas à naçãc, alterada por 21 leis constitucionais e 3 decretos-leis, foi promulgada numa época de intervencionismo, nacionalismo e totalitarismo. Conservava linhas gerais identificadas com o liberalismo, embora na prática concentrasse maior poder nas mãos do Presidente da República, que exercia controle sobre a política legislativa, defendendo os direitos e garantias individuais, da família, educação e cultura, regulando a ordem econômica e salvaguardando a segurança nacional e a defesa do Estađo.

31) BRASIL, Constituições ..., art. 8, I, a v. 1, p. 144.

32) BRASIL, Constituições ...., art. 125, v. 1, p. 171-3.

33) Constitu ção dos Estados Unidos do Brasil de 10 de novembro de 1937. In: BRASIL, Constituịcões ..., v. 1, art. 148, p. 219.

34) BRASIL, Constituições ..., art. 125, v. 1, p. 173.

35) BRASIL, Constituições ..., art. 130, v. 1, p. 174.

36) Constituição dos Estados Unidos do Brasil de 10 de novembro de 1937. In: BRASIL, Constituições ..., v. 1, p. 191-223. 
A Constituição retrata o clima político-econômico existente no país, um país capitalista com uma política governamental pendular, ora protegendo os capitalistas, ora defendendo as classes trabalhadoras, numa economia subdesenvolvida, ligada à exportação de matérias-primas e dominada pelo capitalismo americano.

No que se refere à propriedade, a Constituição de 1937 garante esse direito no art. $122, \S 14$ :

Art. 122 - A Constituição assegura aos brasileiros e estrangeiros residentes no País o direito à liberdade, à segurança individual e à propriedade, nos termos seguintes:

14) $O$ direito de propriedade, salvo a desapropriação por necessidade ou utilidade pública, mediante indenização prévia. O seu conteúdo e os seus limites serão os definidos nas leis que lhe regularem o exercício. ${ }^{37}$

Pelo teor do dispositivo constitucional expressam-se, de modo incisivo, o direito de propriedade e a desapropriação, mediante indenização prévia. O complemento é uma determinação vaga, imprecisa, exigindo a definìção através de leis.

A Constituição de 1937 conserva, no art. 23, inciso I, "a" o mesmo dispositivo da decretaçãc de impostos pelos Estados, apresentado na Constituição de 1934, quando determina:

Art. 23 - da competência exclusiva dos Estados:

I - a decretação de impostos sobre:

a) a propriedade territorial, exceto a urbana..$^{38}$

O mesmo princípio é confirmado no art. $10^{\circ}$, relativo ao art. 23, inciso I, "a", da Lei Constitucional n.0 3, de 18 de setembro de 1940, como segue:

Art. 1.0 - $\mathrm{O}$ art. 13 da. Constituição fica assim redigido: "Art. 23 - É da competência exclusiva dos Estados, salvo a limitação constante do art. 35 , letra "d":

I - a decretação de impostos sobre:

a) a propriedade territorial, exceto a urbana..$^{39}$

37) BRASIL, Constituições ..., art. 122, § 14, v. 1, p. 213-4.

38) BRASIL, Constituições ..., art. 23, I, v. 1, p. 199.

39) Lei Constitucional n. 3 , de 18 de setembro de 1940. In: BRASIL, Constituições ..., art. $1 . \circ$, v. 1, p. 234. 
Ainda no que se refere a impostos, a Constiuição de 1937 dispõe, no art. 28 inciso II, que compete ao município a cobrança do imposto predial e terrítorial urbano, como segue:

Art. 28 - Além dos atribuídos a ele pelo art. 23, § 2.0, desta Constituição e dos que lhes forem transferidos pelo Estado, pertencem aos Municípios:

II - O imposto predial e o territorial urbano..$^{40}$

O mesmo dispositivo constitucional consta do art. 29, inciso I, da Constituição de 1946, que prescreve:

Art. 29 - Além da renda que lhes é atribuída por força dos $\S \S 2 .^{\circ}$ e $4 .^{\circ}$ do art. 15 , e dos impostos que, no todo ou em parte, lhes forem transferidos pelo Estado, pertencem aos Municípios os impostos:

I - predial e territorial urbano. ${ }^{41}$

Continuava, assim, o Governo a controlar a estrutura fundiária e a regulamentar o sistema de taxação de impostos.

A Constituição de 18 de setembro de 1946,42 com 21 Emendas Constitucionais e 4 Atos Institucionais, não se ajusta à renovação liberal, embora ela incentive o atendimeno social por parte do Estado. Apresenta, em relação às Constituições precedentes, alterações mais de ordem formal do que na essência, não cogitando, inclusive, de tirar o poder de uma classe e passar para outra. Não regride ao liberalismo burguês e nem adere ao intervencionismo estatal, tentando uma situação de equilíbrio entre as duas posições.

No plano político, a Constituição de 1946 posiciona-se contrariamente à concentração dos poderes nas mãos do executivo. Mesmo assim ela é objeto de críticas, que apontam falhas e a sua inadaptação à época, tão bem expressás pelo pensamento de Fáivio Lucas:

A crítica que fazemos à Constituição que nos rege o destino é quanto ao seu anacronismo, à sua incorrespondência à época e, principalmente, à sua indecisão, à sua capacidade de res.jizar um jôgo ambíguo, tenso e, portanto, provàvelmente de pouca duraçâo. ${ }^{43}$

40) BRASIL, Constituições ..., art. 28, II, v. 1, p. 200.

41) Constituicões dos Estados Unidos do Brasil de 18 de setembro de 1946: In: BRASIL, Constituições ..., art. 29, I, v. 1, p. 266.

42) BRASIL, Constituições ...., v. 1, p. 257-99.

43) LUCAS, p. 80-1. 
Transformações na conjuntura se fazem sentir através da intensificação de uma política nacionalista, de renovação da vida dos partidos políticos, de tentativa de solução dos problemas nacionais, de defesa das riquezas naturais face a cobiça de nações estrangeiras, de atitude política voltada para a independência nacional.

Bem-estar social, interesse social, justiça social e liberdade de iniciativa constituem postulados fundamentais do direito de propriedade conforme a Constituição de 1946, traduzindo bem o clima reinante, prevendo, inclusive, o uso da propriedade particular em caso de guerra, ou comoção interna, salvaguardando o direito de indenização, como prescreve o art. 141, § $16,{ }^{44}$ a exemplo do que regia a matéria nas Constituições de 1934 e 1937.

O caráter socializante do uso da propriedade é expresso no Título V, Da Ordem Econômica e Social, art. 147, assim enunciado:

Art. 147 - O uso da propriedade será condicionado ao bem-estar social. A lei poderá com observância do disposto no art. $141, \S 16$, promover a justa distribuição la propriedade, com igual oportunidade para todos. ${ }^{45}$

Há, porém, uma dicotomia entre o que é previsto na Constituição e a realidade pcrque a maior parte dos "sem terra" ou se apresentava como posseira, grileira, ou achava-se atrelada a um sistema de exploração do seu trabalho por um grande latifundiário, sem direito à propriedade. A lei complementar não criava mecanismos adequados para estabelecer "igual oportunidade para todos".

A Constituição de 1946, a exemplo das Constituições de 1934 e 1937, não apresenta uma solução ideal para o problema da propriedade, mesmo trazendo perspectivas para a lei abrir caminho para a fixação do homem no campo, através da dinamização de planos de colonização e utilização de terras públicas, com preferência pelo elemento nacional, prevendo a aquisição até vinte e cinco hectares. Consagra, inclusive, o princípio de que a propriedade se legitima pelo uso e pelo trabalho, punindo o proprietário que deixa de explorar a terra e premiando aquele que a utiliza produtivamente. É o que a Constituição prevê no art. $156, \S \S 10^{\circ}$ e $3 .^{\circ}$ :

Art. 156 - A lei facilitará a fixação do homem no campo, estabelecendo planos de colonização e de aproveitamento das terras públicas. Para esse fim, serão preferi-

44) BRASIL, Constituiçōes ..., art. 141, § 16, v. 1, p. 286-7.

45) BRASIL, Constituições ...., art. 147, v. 1, p. 288. 
dos os nacionais e, dentre eles, os habitantes das zonas empobrecidas e os desempregados.

$\S 10^{0}$ - Os Estados assegurarăo aos posseiros de terras devolutas, que nelas tenham morada habitual, preferência para aquisição até vinte e cinco hectares.

$\S 30^{0}$ - Todo aquele que, não sendo proprietário rural nem urbano, ocupar, por dez anos ininterruptos, sem oposição nem reconhecimento de domínio alheio, trecho de terra não superior a vinte e cinco hectares, tornando-o produtivo por seu trabalho e tendo nele sua morada, adquirir-ihe-á a propriedade, mediante sentença declaratória devidamente transcrita. ${ }^{46}$

As alterações constitucionais expressam a realidade histórica brasileira, desde a taxação de inipostos, a desapropriação da propriedade rural pela União, até a determinaçáo das diretrizes gerais sobre planos que incluem desapropriação, visando a reforma agrária. Tudo isto está bem representado na Emenda Constitucional n. ${ }^{\circ} 10$, de 9 de novembro de $1964,{ }^{47}$ cujo art. $2^{\circ}$, que altero' o art. 15 da Constituição de 1946 , acrescido do inciso VII e do $\S 9 .^{\circ},+8$ passou à União a competência para decretar impostos sobre a propriedade territorial urbana, s€ndo o produto da arrecadação entregue aos Municípios onde estivessem localizados os imóveis; no art. $3 .^{\circ}$, deu nova redação ao art. 29 da Constituição e seu inciso I,"' confirmando, além dos impostos previstos na Constituição e dos impostos transferidos pelo Estado, como pertencentes aоs $\mathrm{Mu}$ nicípios, os impostos sobre propriedade territorial urbana. $\mathrm{O}$ art. 4. ${ }^{\circ}$, da referida Emenda Constitucional, dá nova redação ao § 16 do art. 141 da Constituiçâo Fєderal, ${ }^{50}$ garantindo o direito de propriedade, exceto desapropriação por necessidade ou utilidade pública, ou por motivo social, assegurando o direito à indenização, com exceção do que estabelece o art. $147 \S 10^{\circ}$.

$\mathrm{O}$ art. $5 .^{\circ}$, que acrescenta parágrafos ao art. 147 da Constituição Federal, expressa claramente o processo inflacionário que o país vem sofrendo, prescrevendo, no § 1.0,51 a desapropriação da propriedade territorial. rural pela União com o pagamento da indenização em títulos especiais da dívida pública, com correção

46) BRASIL, Constituições ..., art. $156, \S 1 .^{\circ}$ e $3 .^{\circ}$, v. 1, p. 289-90.

47) Emenda Constitucional n. ${ }^{\circ} 10$, de 9 de novembro de 1964. In: BRASIL. Constituições ..., art. $1 . \circ$ v. 1, p. 320 .

48) Art. $2 .^{\circ}$, v. 1, p. 320.

49) Art. $30^{\circ}$, v. 1, p. 320.

50) Art. 4. , v. 1, p. 320.

51) Art. 5. , v. 1, p. 320 . 
monetária, conforme índices estabelecidos pelo Conselho Nacional de Economia, a serem resgatados no prazo máximo de vinte anos, com parcelamenio anual, garantindo-se a aceitação dos mesmos, como forma de pagamento, até cinqüenta por cento do imposto territorial rural $\epsilon$ como modalidade do pagamento do preço de terras públicas.

Mudanças significativas se dão na política governamental no que diz respeito explicitamente à reforma agrária, traduzindo o clima reinante no país. As medidas a serem aplicadas pelo Governo são dirigidas no sentido cie circunscrever o problema às decijsões dos altos poderes da nação, como bem expressa 0 art. $5 .^{\circ}$ da citada Emenda Constitucional:

Art. 5. ${ }^{\circ}$ - Ao art 147 da Constituição Federal são acrescidos os parágrafos seguintes:

“§ 5.0 - Os planos que envolvem desapropriação para fins de reforma agrária serão aprovados por decreto do Poder Executivo, e sua execução será da competência de órgãos colegiados, constituídos por brasileiros de notóvel saber e idoneidade, nomeados pelo Presidente da República, depois de aprovada a indicação pelo Senado Federal.

$\S 6 .^{0}$ - Nos casos de desapropriação, na forma do $\S 1 .^{\circ}$ do presente artigo, os proprietários ficarão isentos dos impostos federais, estaduais e municipais que incidam sobre a transferência da propriedade desapropriada". .2

Seguem as modificações relacionadas com a estrutura fundiária brasileira. $\mathrm{O}$ art. $6^{\circ}{ }^{53}$ que dá nova redação aos $\S \S 10^{0}, 20^{\circ} \mathrm{e}$ $3 .{ }^{\circ}$ do art. 156 da Constituição Federal, estabelece, no $\S 1 .^{\circ}$, o princípio da preferência pelos próprios posseiros localizados nas terras em relação à compra das terras devolutas, até cem hectares; determina, no § $20^{\circ}$, que a alienação ou concessão de terras públicas, com mais de três mil hectares, salvo para colonizaçăo, não poderia ser feita sem prévia autorização do Senado Federal; o § 3.0 confirma o que foi estabelecido nas Constituições de 1934 e 1937, com diferença quanto à área, que não poderia ser maior que cem hectares, mas devendo ser suficiente para garantir, ao lavrador e família, a sua subsistência, bem como o progresso social e econômico, conforme o estabelecido em lei, de conformidade com os sistemas agrícolas regionais.

52) Art. $5 \circ$ v. 1, p. 320-1

53) Art. $6 \circ$ v. 1, p. 321. 
A Emenda Constitucional n. ${ }^{0}$ 18, de $10^{\circ}$ de dezembro de $1965,{ }^{54}$ confirma, no art. $8.0,55$ a competência da União sobre a propriedade territorial urbana, no art. 10,56 a dos Municípios, sobre a propriedade predial e ierritorial urbana e, no art. 20,57 prescreve o repasse da arrecadação do imposto da União aos municípios.

Regulamentando os impostos sobre o patrimônio e a distribuição de receitas tributárias, o Estado continua a exercer jurisdição sobre o instituto jurídico da propriedade, expresso não somente através das Constituições mas, principalmente, da legislação de terras.

A Constituição do Brasil de 24 de janeiro de 1967,58 reflete a situação do país na esfera política, social e econômica. O Estado passou a exercer controle direto sobre todos os setores da vida nacional, inclusive a segurança nacional, o poder judiciário, os partidos políticos, a ordem econômica e social, a família, a educação e a cultura.

Entre os bens da União, a Constituição de 1967 inclui, no art. $4 .^{\circ}$, inciso $I{ }^{59}$ as terras devolutas, necessárias à defesa da nação e ligadas à dinamização da vida econômica. Interligam-se, assim, as terras devolutas a objetivos essencialmente políticos e à esfera econômico-social, cabendo aos Estados, conforme o art. 5. ${ }^{\circ}{ }^{60}$ alémi de lagos e rios em seu domínio e os que têm nascente e foz neles, ilhas fluviais e lacustres, as terras devolutas não contempladas no artigo precedente, ficando, assim, determinado o seu espaço geográfico.

No que se refere à propriedade a Constituição de 1967 consagra, no art. $150 \S 22,{ }^{61}$ esse direito dentro do espírito que norteou o mesmo direito nas Constituições de 1934, 1937 e 1946, com ressalva no que se refere ao disposto no art. 157, § 1.0, ${ }^{62}$ confirmandose a indenização em títulos especiais quanto à dívida ativa, com correção monetária, o que reflete a situaçăo da inflação que tende a se agravar.

54) Emenda constitucional n. ${ }^{\circ} 18$, de $1 .^{\circ}$ de dezembro de 1965. In: BRASIL, Constituições ..., v. 1, p. 338-43.

55) Art. $8 . \therefore$ v. 1, p. 339.

56) Art. 10, v. 1, p. 340.

57) Art. 20, I, v. 1, p. 341.

58) Constituição do Brasil de 24 de janeiro de 1967. In: BRASIL, Constituições ..., v. 1, p. 349-401.

59) Art. $4 . \therefore$, I, v. 1, p. 353.

60) Art. $5 \circ$ v. 1, p. 353.

61) Art. $150, \S 22$ v. 1, p. 391-3.

62) Art. 157, § 1., v. 1, p. 395. 
Quanto aos pīanos sobre reforma agrária, a Constituição de 1967 apresenta, no art. $157 \S 5 .^{\circ},{ }^{6 ; 3}$ a mesma redação do art. 5.0, da Emenda Constitucional n. ${ }^{\circ} 10$, de 09 de novembro de 1964, ${ }^{64}$ que acrescenta ao art. 147 da Constituição Federal de 1946 seis parágrafos, especificamente o $\S 5 .^{\circ}$, continuando a reforma agrária atrelada à vontade do poder executivo, que deveria aprovar planos, incluindo desapropriação, por decreto, cabendo a execução a órgãos colegiados, com membros também nomeados pelo Presidente. da República, após aprovação da escolha pelo Senado Federal, permanecendo tudo subordinado ao arbítrio dos altos poderes.

A C'onstituição de 1967, no texto constitucional então vigente (consolidado), ${ }^{65}$ com a redação dada para a Emenda Constitucional n. ${ }^{\circ}$, de 177 de outubro de 1969 , e as alterações feitas pelas Emendas Constitucionais n. ${ }^{\circ}$ 2/72 a 27/85, estabelece, no art. 21, inciso III e $\S 6 .^{\circ}{ }^{66}$ a competência da União no que se refere à instituição de impostos sobre a propriedade territorial rural, ressalvando os interesses do pequeno proprietário, com área não superior a vinte e cinco hectares, que cultivasse a terra e não possuisse outro imóvel, atendendo, desta forma, uma parcela da população rural.

$\mathrm{O}$ art. 24 , inciso I, $\S \S 10^{\circ}$ e $33 .^{\circ},{ }^{67}$ prescreve a cobrança de impostos pelos municipios sobre a propriedade predial e territorial urbana, determinando a entrega, pelas autoridades arrecadadoras dos tributos aos municípios, das quantias que lhes competiam à medida que fosse sendo realizada a arrecadação.

O texto constitucional então vigente (consolidado) confirma, no art. $153,{ }^{68} \mathrm{a}$ inviolabilidade dos direitos à vida, à liberdade, à segurança e à propriedade e, no $\S 22,{ }^{69}$ assegura esse último direito, salvo o caso de desapropriação, mediante indenização, ressalvado o disposto no art. 161, podendo o expropriado receber o pagamento em título da dívica pública, com correção monetária, permanecendo o direito do uso da propriedade pelas autoridades competentes, no caso de perigo iminente, assegurada a respectiva indenização.

$\mathrm{O}$ art. $153 \S 34,{ }^{70}$ refererite à aquisição da propriedade rural,

63) Art. 157, § $5 .^{\circ}$, v. 1, p. 395.

64) Emenda constitucional n. ${ }^{\circ}$ 10, de 9 de novembro de 1964. In: BRASIL, Constituições .... art. 5, v. 1, p. 320-1.

65) Constitu:ção do Brasil de 24 de ianeiro de 1967, com a redação dada pela Emenda constitucional n. 1 , de 17 de outubro de 1969, e as alterações feitas pelas emendas constitucionais $n .{ }^{\circ}$ s $2 / 72$ a $27 / 85$; texto constitucional vigente (consolidado). In. BRASIL, Constituições ..., v. 1, p. 517-93.

66) Art. 21, III e $\S 6 .^{\circ}$, v. 1, p. 529-30.

67) Art. $24,1, \S 1 .^{\circ}$ e $3 .^{\circ}$, v. 1, p. 533.

68) Art. 153, v. 1, p. 578.

69) Art. 153, § 22, v. 1, p. 578-80.

70) Art. 153, § 34, v. 1, p. 578-81. 
é apenas um paliativo, pois, em vez de reso'ver o problema, determina que a lei estabeleceria regulamentação sobre o caso:

Art. 153

$\S 34$ - A lei disporá sobre a aquisição da propriedade rural por brasileiro e estrangeiro residente no País, assim como por pessoa natural ou jurídica, estabelecendo condições, reșirições, limitações e demais exigências, para a defesa da integridade do território, a segurança do Estado e a justa distribuição da propriedade.

A desapropriação da propriedade rural pela União, prevista no art. $161, \S 1.0^{\circ}$ a $5 .^{0}, 7^{71}$ é feita dentro do mesmo espírito que norteou a elaboração do art. 157, § $1 .^{\circ}$ ao $6 .^{\circ}$, da Constituição de 24 de janeiro de $1967,{ }^{72}$ com maior ênfase, porém, no que se refere ao poder do Presidente da República, cabendo-lhe, como condição privativa, a declaração das zonas prioritárias.

Em síntese, as Constituições tal como foram organizadas, no que se refere à propriedade e à problemática da terra em geral, constituíram, na realidade, instrumentos dialéticos. Acenaram para uma reforma agraria mas, ao mesmo tempo, não criaram organismos para a sua aplicação na prática. Quase sempre eram reclamadas leis ordinárias para a sua realização. As Constituições não apresentaram uma soluçäo formal, cabendo ao legislador ordinário a aplicação de medidas paliativas, registrando-se, mais uma vez, uma incongruência entre a lei e a realidade.

As conquistas de maior alcance, em benefício dos "sem terra" e das classes menos favorecidas só pođlerão ser conseguidas através de sua participação e de um esforço comum de todos junto à Constituinte, encarregada da elaboração da nova Constituição, no sentido de serem criados e agilizados mecanismos, dentro de princípios fundamentados no Direito e na democracia, necessáríos à plena realização dos anseios de contingente expressivo da população brasileira.

Sem uma Constituição que ordene, esclareça os aspectos sombreados pelo cipoal de leis acumuladas e sem entrosamento, continua o caos. Se urge repor o país no direito, é hora de reconduzí-lo ao regime democrático. ${ }^{73}$

71) Art. $161, \S 1 .^{\circ}$ a $5 .^{\circ}$ v. 1, p. 583-4.

72) BRASIL, Constituições ...., art. $157, \S 1 .^{\circ}$ a $6 .^{\circ}$, v. 1, p. 397.

73) IGLÉSIAS, Francisco. Constituinte e constituições brasileiras. 4. ed. São Paulo, Brasiliense, 1987, p. 95. 


\section{Considerações finais}

No seu conjunto, o processo político brasileiro caracteriza-se por uma longa caminhacia, palmilhada de conquistas e fracassos, avanços e recuos, cujos marcos norteadores foram as Constituições, iniciadas com a Constituição do Império (1824), que, mesmo outorgada por $\mathrm{D}$. Pedro I à nação brasileira e sob a inspiração de um absolutismo monárquico, foi abrindo caminho para as outras Constituições brasileiras de 1891, 1934, 1937, 1946, 1967 e a atual. Sob a inspiração das ideologias dominantes nas diferentes épocas, como o liberalismo, a democracia, o positivismo, elas constituíram o documento constitucional que regeu a vida do país, traduzindo a mentalidade da época e representando, inclusive, a expressão do poder da classe dominante, até chegar ao momento atual, em que o povo brasileiro foi convocado a participar da elaboração da nova Constituição, através dos seus órgãos de classe e de seus representantes na Assembléia Constituinte.

As Constituições do Brasil e a legislação de terras são fruto das próprias condições conjunturais e do espírito da época em que foram elaboradas, deixando antever objetivos políticos, sociais e econômicos do Estado e dos outros poderes constituídos, traduzindo mudança de mentalidade e tendência de ajuste aos interesses das classes dominantes, muitas vezes sem atender aos reclamos do povo brasileiro, partindo de uma concepção acentuadamente nacionalista para uma maior abertura em relação à problemática mundial.

Embora as Constituições brasileiras demonstrem que, no que se refere ao direito de propriedade, ela sempre foi considerada como um direito pleno, com todas as garantias, prevendo, no caso do uso da propriedade a indenização, preservando o direito do não proprietário rural ou urbano, em caso de cultura efetiva e morada habitual, por determinado período contínuo, elas não criaram mecanismos para atender a necessidade de parte da população sem condições de adquirir a terra e explorá-la economicamente.

Mesmo que a Lei de Terras de 1850 e o seu Regulamento de 1854 tivessem esboçado uma tentativa de reforma agrária, tendo implantado o sistema de compra e procurado garantir os direitos dos posseiros, mediante a legitimação das posses, contribuindo para a institucionalização da pequena propriedade, nem ela e nem a legislação de terras posterior possibilitaram uma solução para o o problema da terra. O problema fundiário faz parte de um processo muito mais amplo, que não pode se limitar à mera redistribuição de terras. Implica numa reforma institucional profunda, numa reforma de estrutura do poder, numa reforma de aplicação da justiça, numa reforma social, que possibilite a solução dos problemas ligados à propriedade e ao homem. 
As Constituições, tal como foram organizadas no Brasil, na verdade são mero instrumento dialético. No que tange à terra e à propriedade agrária, ac mesmo tempo que prometiam resolver a situação, deixavam de criar mecanismos para a sua aplicação na prática. Reclamavam-se leis ordinárias para a realização da reforma agrária, cabendo ao legislador a aplicação de medidas legais paliativas, registrando-se, mais uma vez, a dicotomia entre a lei e a realidade. Ainda hoje o Brasil se vê desafiado para a solução constitucional da reforma agrária.

Alguns dos poucos resultados foram obtidos com custos: custos políticos, em termos da não afirmação, na prática, dos direitos do povo brasileiro; custos sociais, representados pelas desigualdades na distribuição da. propriedade, sendo, portanto, expressivo o contingente dos "sem terra"; custos econômicos, identificados com as grandes extensões territoriais sem qualquer tipo de exploração econômica. Daí a urgência e a necessidade de uma reforma agrária que atente para a solução dos graves problemas nacionais.

Assim sendo, a nova Constituição deverá apresentar solução não somente para o problema agrário mas para um salário condigno para o trabalhador, garantindo o direito à educação, saúde e habitação, o direito à liberdade, igualdade e maior participação na vida política da nação.

A síntese dos elementos constitucionais que tiveram permanência, aliada aos elementos renovadores, imprimiu uma fisionomia própria e original à nova. Constituição. Resta saber até que ponto ela corresponderá aos anseios de modernidade e de adaptação à nova realidade brasileira.

\section{Legislação de terras decorrentes do processo de coloniza- ção implantado por Portugal no Brasil}

\section{Introdução}

Rui Cirne Lima sintetiza, numa frase, a origem da tradição agrária em nosso país:

A história territorial do Brasil começa em Portugal. ${ }^{74}$

Portugal descobriu e colonizou o Brasil e deu-lhe toda uma estrutura jurídica, calcada no Direito Português.

E o que confirmam as palavras de Marcelo Caetano:

74) LIMA, Ruy Cirne. Pequena história territorial do Brasil; sesmarias e terras devolutas 2. ed. Porto Alegre, Sulina, 1954, p. 11. 
Queiramos ou não, o Direito Brasileiro e o Direito Português são parentes próximos. A ascendência comum é inegável: a História do Direito Português contém a árvore genealógica da maior parte dos institutos jurídicos vigentes no Brasil. E por muito que se tenham diferenciado as condições sociais da velha Pátria lusitana e da pujante nação americana, restam na sociedade brasileira traços inconfundíveis de mentalicade e costumes que favorecem a persistência de normas de conduta, evoluída a partir da herança ancestral. ${ }^{75}$

A colonização do Brasil foi expressa, no campo jurídico, pela introdução das instituições do Direito Público e Privado Português, principa'mente a das sesriarias, regulamentada pelas cartas de doação, que estabeleciam a. legitimidade da propriedade, pelos antigos forais, que confirmavam a subordinação dos que recebiam as terras de sesmarias ao poder estabelecido, capitães-mores, donatários e, em última instância, o rei de Portugal, e pelas leis gerais, consubstanciadas nas Ordenações Afonsinas, Manuelinas e Filipinas.

Estabelece-se, assim, uma hierarquia social baseada na terra, o que constitui um dos eixos fundamentais da estrutura fundiária e da sociedade brasileira, representada, inicialmente, por fidalgos, colonos, gentios.

Daqui si ve que o regimen das capitanias doadas hereditariamente instituia uma hierarquia de senhores territoriaes, que tinha o rei no cimo, tendo nos degráos inferiores o donatario e o sesmeiro ou colono. ${ }^{76}$

Dessa forma, o Estado Fortuguês impunha uma ordem jurídica, social e econômica de cima para baixo, subordinando todos às ordens da Coroa.

A fundação de uma povoação exigia o estabelecimento de uma ordem municipal e isto era feito através da eleição de juízes e vereadores. Os reinóis kuscavam, na memória, fonte de inspiração para a aplicação dos mecanismos socıais e político-administrativos.

75) CAETANO, Marcello. As sesmarias no direito luso-brasileiro, in: __. Estudos de direito civil brasileiro e português. São Paulo. Revista dos Tribunais, 1980 , p. 9.

76) MARTINS JUNIOR. Historia do direito nacional. 2 ed. Pernambuco, Cooperativa Editora e de Cultura Intelectual, 1941, p. 153. 
Inevitavelmente o que daí em diante decorria era a adaptação de algumas iciéias e práticas, retidas na memória, às circunstâncias do local, onde sobretudo importava que se implantassem alguma eqüidade e segurança. ${ }^{77}$

Dessa forma, a regulamentação jurídica vai surgir como uma necessidade ditada pelo meio e pelas circunstâncias históricas. A legislação portuguesa passou por uma série de adaptações e transformações, sendo possível afirmar que, lado a lado do Direito Português, aplicam-se normas, práticas, soluções, constituindo-se uma espécie de Direito costumeiro, fruto da experiência local, que, com o tempo, deveria ser cociificado. A ocasião propícia viria com a emancipação, a afirmação política, isto é, com a Independência do Brasil (1822). Após a Ir.lependência criam-se as bases para o estabelecimento dos monumentos jurídicos do Direito Brasileiro, que são os Códigos, expressão de uma consciência bastante eiitista, representada, no decorrer do século XIX e no século XX por uma intelligentsia jurídica e política. Mais recentemente é que o povo, como massa, tenta participar, através dos seus representan. tes, da vida política, social e econômica do país.

\subsection{A estrutura fundiária do Brasil}

$\mathrm{Na}$ raiz de toda a estrutura agrária brasileira encontra-se a sesmaria. $O$ instituto da sesmaria, concessão enfitêutica, cujo vocábulo provém, para alguns, de sesma, espécie de medida de divisão das terras do alfoz ${ }^{78}$ para outros, de sesma ou sesmo, indicativo da sexta parte de uma cousa, ${ }^{79}$ ou do baixo latim caesina, que se liga a incisão, corte, ${ }^{80}$ constitui o eixo fundamental da concessão de terras.

A definição de sesmarias, tanto nas ordenações Manuelinas, como nas Filipinas, é:

Sesmarias são propriamente as dadas de terras, casaes ou pardieiros, que foram, ou são de alguns senhorios, e que já em outro tempo foram lavradas e aproveitadas é agora o não são. ${ }^{81}$

77) CAETANO, p. 10.

78) SILVA FERREIRA. Repertorio das ordenações e leis de Portugal. Coimbra, 1795. t. 4 verbete sesmaria, nota a, p. 660. Citado por LIMA, p. 15.

79) PEREIRA E SOUZA. Diccionario juridico. Lisboa, 1827. Verbete sesmaria. Citado por LIMA, p. 15.

80) LIMA, p. 15

81) LIMA, p. 21. 
O Direito Português procurou conciliar o interesse público, no sentido de favorecer a subsistência das populações, com o interesse privado, regulamentando 0 aproveitamento de pastos, de servidôes de água e de caminhos e de logradouros públicos.

Devido às condições geográficas, as sesmarias no Brasil caracterizaram-se pela concessãc de vastas áreas territoriais, que vinham beneficiar uma elite agrária, que se comprometia, e muitas vezes não cumpria, a povoar e explorar economicamente as concessões, em prejuízo de outros colonos, que não dispunham de prestígio político, ou social, de capital e de escravaria.

A famosa lei das sesmarias, de D. Fernando, promulgada no final do século XIV, provavelmente 1375, traz no seu bojo a essência de uma reforma agrária, objetivando incentivar o trabalho dos ociosos e o cultivo de terras incultas, como condições essenciais para a confirmação da posse da terra, prevendo a apropriação da terra ainda inculta. O instituto da sesmaria era muito mais antigo e a lei das sesmarias de D. Fernando não regulamentou, não definiu, não atualizou. Ela permaneceu ligada ao antigo Direito Português e, como tal, passou ao Brasil, sendo exigidas, para a sua efetivação, uma série de formalidades, incluindo demarcação e cultura.

Ao lado da concessão de sesmarias desenvolve-se o processo de ocupação ilegal de terras públicas. O Estado não possuia uma estimativa do seu patrimônio, precisava reaver as terras devolutas, que lhe pertenciam, necessitava aunientar a sua renda, mediante a cobrança de impostos, bem como garantir o povoamento da zona de fronteira, numa época de necessidade de afirmação do uti possidetis, e regulamentar a propriedade, principalmente na zona litorânea, onde se localizavam as principais cidades. A possessão era uma forma de negação do Estado, da autoridade, do poder constituído.

Sobre a propriedade da terra, Warren Dean coloca, com muita propriedade, o seguinte problema:

Se a maior parte da terra possuída privativamente fora adquirida ilegalmente, como poderia o Estado manter os direitos individuais à propriedade? ${ }^{82}$

Complementando, podemos propor: Como ficaria a situação do Estado diante da perspectiva de ter que conhecer a situação real das terras, distinguindo aquelas que haviam sido regularmen-

82) DEAN, Warren. Os latifúndios e a política agrária brasileira no século XIX. In: PELAEZ, Carios M. e BUESCU, Mircea. A moderna história econômica. Rio de Janeiro. APEC, 1976, p. 248. 
te adquiridas, daquelas obtidas por posse, ou que estavam sendo ocupadas, sem ferir direitos anteriormente adquiridos? Em que medida o Estado poderia exercer o papel de legislador, árbitro das disputas, fiscalizador e regulamentador no que se refere ao problema de terras?

A margem da lei, firmava-se o instituto jurídico da ocupação das terras devolutas, como fruto das circunstâncias históricas e transformações conjunturais. Dentre elas inclui-se, inicialmente, a cessação das concessões de cartas de sesmarias, pelo ato de 17 de julho de 1822, caracterizado como uma insurreição contra a coroa portuguesa, já que as sesmarias eram uma concessão do rei de Portugal. Outro eiemento importante foi a falta de pronunciamento da Assembléia Geral Constituinte do Império, que não regulamentou o instituto jurídico das concessões de terras, não constando na Constituição de 25 de março de 1824 . O grande entrave era a situação caótica que se registrou no período de aproximadamente três décađas, de 1822 a 1850, em razão do aumento da ocupação ilegal das terras, juntando-se um problema de ordem técnica, ou seja, a dificuldade de medições, devido à falta de pessoal capacitado.

o que tornou o regime jurídico das concessões de cartas de sesmarias sistematicamente desobedecido e as terras sesmariais sistematicamente intrusadas. ${ }^{83}$

O problema exigia uma solução que satisfizesse, principalmente, as classes dirigentes.

O próprio sistema capitalista brasileiro da época, fundamentado na exportação de produtos primários, sobretudo o café, plantado no Rio de Janeiro e depois em São Paulo, e as lideranças políticas, representadas por membros da corte, muitas vezes parentes próximos dos "barões do café", estava a exigir uma política favorável, em detrimento dos usucapientes que, mais cedo, ou mais tarde, haveriam de fazer concorrência na procura da mão-de-obra e na tentaćiva de obtenção de crédito bancário.

Interessava às lideranças lima política que garantisse os seus direitos e estabelecesse uma ordem favorável à aristocracia cafeeira capitalista da época, que não podia ser ameaçada, ou prejudicada. Tudo fazia parte, inclusive, da política ministerial, ora dirigida por conservadores, ora por liberais.

Significativas transformações na socicdade deram-se com a abolição gradual da escravidão e a entrada de imigrantes, trabalhadores livres, que, em expressivo contingente, iriam dedicar-se a atividades agrícolas.

83) JUNQUEIRA, Messias. $O$ instituto brasileiro das terras devolutas. São Paulo, LAEL, 1976, p. 87. 
As lideranças políticas procuraram solucionar o problema com uma lei de terras que regulamentasse a situação das terras devolutas, das terras possuíaas por título de sesmaria, sem regulamentação legal, bem como das posses.

\subsection{A tentativa de regulamentação da posse e da propriedade}

O Conselho de Estado, em 1842, elaborou proposta ,apresentada em 1843, fundameniada nos ideais dos proprietários de terras. Bernardo Pereira de Vasconcelos e José Cesario de Miranda Ribeiro inspiraram-se nas idéias de Edward Gibbon Wakefield, autor de Letters from Sydney, publicadas em 1829. O seu plano consistia em substituir a política dos grandes domínios pela venda de terras de tamanho limitado, a um preço bastante elevado, porque, a baixo preço, poderia esvaziar as unidades produtivas de mão-de-obra e aumentar a demanda de novos escravos.

O defensor do projeto no Conselho de Estado, Rodrigues Torres, confirmou:

Desejamos garantir que os trabalhadores livres provenientes de outras partes do mundo não encontrem terra da Coroa imediatamente para assim trabalharem para os plantadores por algum tempo. ${ }^{8+}$

Há um certo sentido nacionalista por parte das autoridades e das lideranças locais, que poderiam ver no imigrante, conforme o caso, um competidor em potencial, ou mesmo um rival, pondo em risco o seu poder.

O pensamento da época está condensado na Lei n. ${ }^{\circ} 601$, de 18 de setembro de $1850,{ }^{85}$ que regulamentou o instituto jurídico das terras devolutas no Brasil, com diversos pontos calcados na Lei Norte-americana de Terras, de 1785. A Lei de Terras de 1850 traz consubstanciada no seu bojo uma reforma agrária, estabelecendo:

Art. $1^{\circ}$ - Ficão proibidas as acquisições de terras devolutas por outro titulo que não seja o de compra. Exceptuão-se as terras situadas nos limites do Imperio com paizes estrangeiros em huma zona de dez leguas, as quaes poderão ser concedidas gratuitamente. ${ }^{86}$

84) TORRES, Rodrigues. In: DEAN, p. 250. (BCD-A, 1843, pt. 2, 11, 380-1).

85) BRASIL. Leis, decretos etc. Lei $n 0^{\circ} 601$, de 18 de setembro de 1850, In:

Collecção das leis do Imperio do Brasil de 1850. Rio de Janeiro, Typ. Nacional, 1851. t, 1, pt. 1, sec. 44, p. 307-13.

86) BRASIL,Collecção dás leis . .., art. $1 .^{\circ}$, t. 11 , pt. 1 , sec. 44, p. 307. 
Institucionaliza-se a obtenção das terras pela compra, excetuando as terras limítrofes que, no sentido de incentivar o povoamento, seriam concedidas aos peticionários que as solicitassem.

As terras devolutas foram especificadas na referida Lei, que passa a regulamentar a estrutura fundiária brasileira:
Art. 3.0 - São terras devolutas:
$\S 1 .^{\circ}$. As que não se acharem applicadas a algum uso pu- blico nacional, provincial, ou municipal.
$\S 2 .^{\circ}$. As que não se acharem no dominio particular, por qualquer titulo legitimo, nem forem havidas por sesma- rias e outras concessôes do Governo Geral ou Provincial, não incursas em commisso por falta do cumprimento das condições de medição, confirmação e cultura.
$\S 3.0$. As que não se acharem dadas por sesmarias, ou outras concessões do Governo, que, apezar de incursas em commisso, forem revalidadas por esta Lei. ${ }^{87}$

A Lei de Terras estabeleceu, no art. $4 .{ }^{0,88}$ a revalidação das sesmarias, ou outras concessões do Governo Geral, ou Provincial, com cultivo, ou com princípio de cultura, bem como morada habitual e, no art. 5.0,39 a legitimação das posses mansas e pacíficas.

$\mathrm{O}$ art. 10.090 firmou a obrigação do Estado em distinguir o domínio público do particular, isto é, coube ao Poder Público a tarefa de demarcar novas terras, separando-as das que não eram devolutas. Este dispositivo constituía um desafio ao Poder Público.

$\mathrm{O}$ art. $11^{91}$ determinou que os posseiros receberiam títulos fornecidos por Repartições Provinciais, a serem designadas, pagando cinco mil réis por terreno de um quadrado de 500 braças por lado, aumentando a quota com a área, além de quatro mil réis de despesa com outros emolumentos ou selo.

Conforme o art. $14,{ }^{92}$ as terras devolutas seriam vendidas em hasta pública, ou por outra forma, em lotes de quinhentas braças por lado, perfazendo a área total de 20.000 braças quadradas.

87) BRASIL, Collecção das leis . ., art. $3 .^{\circ}, \S 1 .^{\circ}$ a $3 .^{\circ}$, t. 11 , pt. 1 , sec. 44 , p. 308.

88) BRASIL, Collecção das leis .... art. $4 .^{\circ}$, t. 11 , pt. 1 , sec. 44 , p. 308.

89) BRASIL, Collecção das leis ..., art. $5 .^{\circ}$, t. 11, pt. 1, sec. 44, p. 308-9.

90) BRASIL, Collecção das leis .... art. $10 .^{\circ}$, t. 11 , pt. 1 , sec. 44, p. 310.

91) BRASIL, Collecção das leis ..., art. $110^{\circ}$, t. 11 , pt. 1, sec. 44 , p. 310.

92) BRASIL, Collecção das leis ..., art. $14 .^{\circ}$ t. 11 , pț. 1, sec. 44 , p. 310-11. 
A Lei n. ${ }^{\circ} 601$ regulamentou melhor a situação das terras devolutas quando propôs, no art. $21,{ }^{93}$ a criação da Repartição Geral das Terras Públicas, com a finalidade de medição, divisão e descrição das terras devolutas, além da sua conservação, das vendas e distribuição, objetivando a promoção da colonização nacional e estrangeira.

Mas não era apenas o pioblema agrário que preocupava o Governo. O Brasil mostrava-se interessado em conhecer a sua população e, em meados do século passado, o Governo seria encarregado de realizar o censo geral do Império, com características das diversas Privíncias, de modo a regulamentar os registros de nascimentos e óbitos.

A Lei de Terras vai de encontro a esse compromisso do Governo e, dentro do seu campo de ação, dispôs, no art. $13,{ }^{94}$ que deveria ser organizado, por Freguesias, o registro das terras possuídas, baseado nas declarações realizadas por seus possuidores, baixando multas e penas sobre aqueles que nãc cumprissem as disposições legais nos prazos estabelecidos, ou que as fizessem de modo inexato. O governo procurava, dessa forma, conhecer o seu patrimônio de terras devolutas, respeitando direitos anteriormente adquiridos.

O registro das terras possuídas perante o vigário seria o primeiro passo para conhecer a situação agrária. O registro paroquial, regulamentado nos arts. 91 a 107, do Regulamento de 1854, ${ }^{95}$ era obrigatório para os possuidores de terras, com qualquer titulação ou possessão; para os proprietários de sesmarias, concessões regulares; para sesmarias sem confirmação, mas que passaram para outros por títulos; para posses que haviam sido transferidas por títulos legítimos, com sisa quitada conforme a Lei de Terras; para sesmarias que deveriam submeter-se a processo de revalidação e de posses que seriam legitimadas.

A sociedade apresentava uma grande distinção entre proprietários e posseiros, entre ricos e pobres. Não seria uma Lei de Terras que iria resolver todos os problemas, criando uma sociedade com iguais direitos e oportunidades para todos.

A questão é que o Império pretendia resolver um problema institucional, de ordem econว̂mico-social, por meio de uma Lei de Terras e do seu Regulamento, ato puramente administrativo, como confirma Messias Junqueira:

93) BRASIL, Collecção das leis ..., art. 21. . t. 11, pt. 1, sec. 44, p. 312.

94) BRASIL, Collecção das leis ..., art. $13^{\circ}$ t. 11 , pt. 1 , sec. 44 , p. 310.

95) Decreto n. 1318, de 30 de janeiro de 1854, para execução da lei n. 601 , de 18 de setembro de 1850, a que se refere o decreto desta data. In: Brasil, Collecção dás leis ..., de 1854, arts. 91-107, t. 17, pt. 2, p. 10-28. 
Se o legislador de 1850 adotou o processo administrativo das terras devolutas do Império, foi a isso levado simplesmente porque a êsse tempo estavam muito em moda as teorias administrativas, um poder administrativo judicante, um tribunal "sui generis" para a solução de questões entre as quais podia ser alinhada a de apuração da propriedade pública sobre as terras devolutas recémconceituadas. ${ }^{96}$

Mesmo não solucionando todos os problemas, a Lei de Terras trouxe transformações no panorama da estrutura fundiária. Ëla institucionalizou a pequena propriedade no Brasil. A propriedade da terra perdeu a característica de um privilégio, de um fator de desigualdade social, e passou a ser considerada mercadoria. Contribuiu para a democratização da estrutura social, reconhecendo a figura jurídica da posse e do posseiro, admitindo-o num status social. ${ }^{97}$ Criada para uma época histórica, a Lei de Terras transcendeu no tempo, regulamentando uma situação caótica e projetando-se no futuro, sendo aplicada para dirimir dúvidas e dar as diretrizes no que se refere a terras devolutas, posse e propriedade.

O modelo de Wakefield, aplicado em alguns princípios da Lei de Terras, expressos nos arts. 18, 14, § 2 e 19,98 contribuiu para a obtenção de alguns resultados positivos. $O$ art. 18 incumíia $o$ Governo de importar colonos livres com o objetivo de empregálos em estabelecimentos agrícolas, em trabalhos dirigidos pela administração pública, ou na constituição de colônias, garantindolhes o emprego; o art. 14, já citsdo, autorizou o Governo a vender as terras devolutas, devendo medir, dividir, demarcar e descrever as terras colocadas à venda; no mesmo art. $14 \S 2$, foi estabelecido o preço de venda,com pagamento a vista, relativo a meio real, um real, real e meio e dois réis, por braça quadrada, conforme a qualidade e localização dos lotes; o art. 19 determinou que o produto dos direitos da Chancelaria e da venda das terras seria aplicado na medição de terras devolutas e na importação de colonos livres. A Lei de Terras articula-se ao contexto histórico da época, caracterizado pela gradual substituição do trabalho escravo livre, inicialmente com a proibição do tráfico de escravos em 1850, pelo incentivo da venda de terras e pela dinamização da colonização européia.

96) JUNQUEIRA, Justificativa e ante-projeto da lei de terras (conclusão de trabalho juridico). In: MOURA, Mário de Assis. Terras devolutas. São Paulo, Saraiva, 1946 , p. 89.

97) JUNQUEIRA, p. 99.

98) Lei n.-601 de 18 de setembro de 1950. In: BRASIL, Collecção das leis ..., de 1850, art. 18, 14 § 2, 19, p. 310-12. 
Partidários de diferentes facções políticas aprovaram a aplicação da Lei de Terras e do seu Regulamento, considerando que ela viera resolver não questões partidárias mas aquelas referentes ao bem comum, como as de matéria fiscal e de melhoria das condições do país. É o que confirma notícia publicada em jornal de prestígio da Corte, o Jornal do Commercio:

Temos ouvido a seu respeito o juizo favoravel de homens illustrados das diversas opiniões politicas; nem as questões que o Regulamento veio resolver' são questões de partido, mas sim de bem commum, de interesse fiscal, e de engrandecimento do paiz..$^{99}$

Se o poder dos grandes proprietários saiu fortalecido com a Lei n. ${ }^{0}$ 601, outras transformaçeõs seriam registradas nas estruturas político-econômico-sociais, principalmente com a abclição da escravatura (1888) e a instalação da República (1989). No cenário social, com a desagregação da sociedade tradicional agrária, surgem novas lideranças, que haveriam de conduzir os destinos do país. O problema das terras devolutas continuaria em aberto, constituindo um desafio para os governos republicanos.

A par da Lei de Terras de 1850 e seu Regulamento, ${ }^{100}$ que regulamentou a Repartição Geral das Terras Públicas, a medição das terras públicas, a revalidação e legitimação das terras, a venda de terras públicas, os registros das terras possuídas e outros aspectos, foi estabelecida uma legislação de terras, inclusive referente a terras devolutas. Fazem parte desse elenco de documentos legais o aviso de 8 de maio de 1854,101 que dá regulamento provisório para a medição e demarcação das terras devolutas e particulares; a portaria n. ${ }^{3} 385$, de 19 de dezembro de $1855,{ }^{102}$ que manda observar provisoriamente as Instruções práticas organizadas pela Repartição Geral das Terras Públicas; o decreto n.0 3784, de 19 de janeiro de $1867,{ }^{103}$ que aprova o Regulamento para as eo-

99) Regulamento para a execucão da lei de terras. In: VASCONCELLOS, J. M. P. Livro das terras ou collecção da lei, regulamentos e ordens expedidas a respeito desta materia até o presente. Rio de Janeiro, Laemmert, 1860, p. 410.

100) Decreto n. 1318 , de 30 de janeiro de 1854. In: BRASIL, Collecção das leis ... de 1854, t. 17, p.. 2, p. 10-28.

101) Aviso de 8 de maio de 1854. Dá regulamento provisorio para a medição e demarcação das terras devolutas e particulares. In: BRASIL, Leis, decretos, etc. Collecção das decisões do governo do Imperio do Brasil, 1854. Rio de Janeiro. Typ. Nacional, 1854, p. 109-27.

102) Portaria $n .^{\circ} 385$, de 19 de dezembro de 1855. Manda observar provisoriamente as instrucções praticas organizadas pela Repartição Geral das Terras Publicas. In: BRASIL, Collecção das decisões ..., 1855, t. 18 p. 433-51.

103) Decreto n. ${ }^{\circ} 3784$, de 19 de ianeiro de 1867. Approva o requlamento para as colonias do Estado. In: BRASIL, Collecção das leis ... de 1867, t. 30, pt. 2 , p. $31-40$. 
lônias do Estado, e o decreto n. ${ }^{0}$ 6129, de 23 de fevereiro de 1876, ${ }^{104}$ que organiza a Inspetoria Geral das Terras e Colonização.

Com a Proclamação de. República, a jurisdição das terras devolutas transfere-se aos Estados, sendo prevista no art. 64, da Constituição de 1891, exceto no que se refere ao Território do Acre. ${ }^{105}$ No Paraná, a lei n. ${ }^{0} 68$, de 20 de dezembro de $1892,{ }^{106}$ regulamentou as terras devolutas.

A venda de terras devolutas passou por uma transformação com a instituição da obrigatoriedade do registro da matrícula do imóvel no Registro Torrens, surgido na Austrália (lei de ...... 27.01.1858) e aplicado nos Estados Unidos e Canadá. Os líderes do Governo Provisório da recém instalada República do Brasil, que procuravam adaptar novas idéias à realidade brasileira, impiantaram o Registro Torrens, pelo decreto n. $451-\mathrm{B}$, de 31 de maio de $1890,{ }^{107}$ com exposição de motivo assinada por Rui Barbosa, Manuel F. de Campos Salles e Francisen Glicerio.

Modalidade prática, objetiva de registro de imóveis, assentado na unicidade do título, com o quadro completo da situação jurídica do imóvel, o registro Torrens isentava de qualquer tipo de dúvida o imóvel rural nele registrado. Mesmo não havendo menção a ele no Código Civil, o Registro Torrens continuou a ter validade, sendo regulamentado pelo Código de Processo Civil, no título XXII, arts. 457 a $464,{ }^{10 *}$ sofrendo posterior regulamentação.

Coube ao Ministério da Agricultura, criado pela lei n. ${ }^{0} 1606$, de 29 de dezembro de $1902,{ }^{109}$ supervisionar serviços relacionados com as terras públicas, registro de terras possuidas, legitimação e revalidação de posses e concessões.

Solucionados os problemas com o território do Acre (Tratado de Petrópolis), a Bolívia e o Peru, o Governo mandou aplicar o decreto n. ${ }^{\circ} 2543 \mathrm{~A}$, de 5 de janeiro de $1912,{ }^{110}$ pela qual eram re-

104) Decreto n. ${ }^{\circ} 6129$, de 23 de fevereiro de 1876. Organiza a Inspectoria Geral das Terras e Colonização. In: BRASIL, Collecção das leis de 1876, t. 39, pt. 2, v. 1, p. 247-55.

105) Constituição da República dos Estados Unidos do Brasil de 24 de fevereiro de 1981. In: BRASIL. Constituiçõ€s — art. 64, p. 98.

106) PARANA. Leis, decretos, etc., Lei n. 68 , de 20 de dezembro de 1892 . Regulamenta as terras devolutas. In: ——. Leis e regulamentos do Estado do Paraná. Curityba, Typ. Penitenciaria do Ahu, 1892, p. 41-7.

107) Decreto n. 451 B, de 31 de 1890. Estabelece o Registro e transmissão de immoveis pelo systema Torrens. In: BRASIL, Leis, decretos. etc. Decretos do governo provisorio da republica dos Estados Unidos do Brazil. Rio de Janeiro, Imp. Nacional, 1890, p. 1206-20.

108) BRASIL. Leis, decretos, etc. Codigo de processo civil: decreto-lei n. 1608 , de 18 de setembro de 1939 e leqislação complementar, 6. ed. Rio de Janeiro, Forense, 1968, art. 457 a 464 , p. 154-6.

109) Lei n. 1606 , de 29 de dezembro de 1906. In: JUNQUEIRA. $O$ instituto brasileiro de terras devolutas, p. 103.

110) Decreto n. 2543 A, de 1912. In: JUNQUEIRA, p. 102. 
conhecidas as posses das terras devolutas do Acre, seguindo a exped'cão de Títulos da propriedade pela União. As providências prometidas por este decreto se completam no decreto n. ${ }^{0} 10105$, de 5 de março de $1913,{ }^{11}$, que procurou aplicar na República o sistema estakelecido pela Lei n.o 601, de 1850, e do seu Regulamento de 1854, criando comissários de terras para tarefas administrativas e recebimento dos registros de terras e do processo judicial. Foi substituído, por falta de infra-estrutura administrativa, pelo decreto n. ${ }^{0} 11485$, de 10 de fevereiro de $1915 .{ }^{112}$

O decreto-lei n. ${ }^{0}$ 9760, de 5 de setembro de $1946,{ }^{113}$ nova lei de terra relativa aos bens imóveis da União, criou o Conselho de Terras da União para dirimir conflitos entre a União e particulares, sendo extinto pelo decreto n..$^{\circ} 73977$, de 22 de abril de 1974. ${ }^{114}$ A União passou a exercer a sua ação através do Instituto Nac'onal de Colonização e Reforma Agrária - INCRA.

O Estatuto da Terra, estabelecido pela lei n. ${ }^{\circ} 4504$, de 30 de novembro de $1964,{ }^{115}$ fruto do compromisso firmado pelo Brasil em Punta del Este, com outras repúblicas americanas, deixa perceber claramente objetivos políticos, sociais e econômicos, não alcançando a sua plena realização porque estão em jogo interesses antagônicos e divergentes na política brasileira.

O eixo inicial e fundamental do Estatuto da Terra é previsto no

Art. $10^{0}$ - Esta Lei regula os direitos e obrigações concernentes aos bens imóveis rurais, para os fins de execução da Reforma Agrária e promoção da Política Agrícola. ${ }^{116}$

Define a Reforma Agrária e a Política Agrária como sendo:

Art. $10^{\circ}$

§ 1.0 Considera-se Reforma Agrária o conjunto de medidas que visem a promover melhor distribuição da terra, mediante modificações no regime de sua posse e uso, a fim de atender aos princípios de justiça social e ao aumento de produtividade.

111) Decreto n. 10105, de 5 de março de 1915. In: JUNQUEIRA. p. 104.

112) Decreto n. 11485, de 10 de fevereiro de 1915. In: JUNQUEIRA, p. 105.

113) Decreto-lei n. 9760 , de 5 de setembro de 1946. In: JUNQUEIRA, p. 106.

114) Decreto n. 73977 , de 22 de abril de 1974. In: JUNQUEIRA, p. 106.

115) BRASIL. Leis, decretos etc. Estatuto da terra, lei n. 4504 , de 30 de novembro de 1964, Brasiiia, INCRA, 1964, p. 14-52.

116) BRASIL. Estatuto da terra art. $1 . \therefore$ p. 14. 
$\S$ 2.․ Entende-se por Política Agrária o conjunto de providências de amparo à propriedade da terra, que se des. tinem a orientar, no interesse da economia rural, as atividades agropecuárias, seja no sentido de garantir-lhes o pleno emprego, seja no de harmonizá-las com o processo de industrialização do País. ${ }^{117}$

Objetiva-se, com a Reforma Agrária, introduzir transformações na estrutura fundiária, visando o atendimento à justiça social e à dinamização da produção. No que se refere à Política Agrária, esboçam-se medidas de proteção à propriedade da terra, tendo como eixo central as atividades agropecuárias, procurando estabelecer uma correlação estreita com o processo de industrialização brasileira. belece:

Garantindo o direito à propriedade, o Estatuto da Terra estaArt. $2 .^{\circ}$ - E assegurada a todos a oportunidade de acesso à propriedade da terra, condicionada pela sua função social, na reforma prevista nesta Lei.

$\S 1 .^{\circ}$. A propriedade da terra desempenha integralmente a sua função social quando, simultaneamente:

a) favorece 0 bem-estar dos proprietários e dos trabalhares que nela habitam, assim como de suas famílias,

b) mantém níveis satisfatórios de produtividade;

c) assegura a conservação dos recursos naturais;

d) observa as disposições legais que regulam as justas relações de trabalho entre os que a possuem e a cultivam. ${ }^{118}$

O texto legal expressa a filosofia que lhe serve de sustentácu1o, que garante, acima de tudo, o direito à propriedade, ligando-j à sua função social, e caracterizanđo as formas em que a propriedade da terra exerce a função social, incluindo o bem estar de proprietários e trabalhadores da terra, a produtividade, a conservação de recursos naturais e a observância das disposições legais nas relações de trabalho.

O Estatứo da Terra estabeleceu um órgão executor específico para a realização da reformঊ, agrária, o Instituto Brasileiro de Re. forma Agrária (IBRA), além de Delegacias Regionais do referido Instituto e Comissões Agrárias, regulamentado nos arts. 37 a

117) BRASIL, Estatuto da terra, art. $1 .^{\circ}$, $10^{\circ}$ e $2 .^{\circ}$, p. 14.

118) BRASIL. Estatuto da terra, art. $2 .^{\circ}, \S 1 .^{\circ}$ a-d. p. 14. 
42, ${ }^{119}$ bem como instituiu um Fundo Nacional de Reforma Agrária, conforme os arts. 27 a $31,,^{120}$ com recursos provenientes, entre outros, da Contribuição de Melhoria e de $3 \%$ da receita tributária da União, estabelecendo que a reforma agrária deve se fundamentar na realização de planos nacional e regionais, com prazos determinados e em correlação com os seus objetivos.

Dentro do espírito da ambigüidade, marcante em toda a legislação brasileira, o Estatuto da Terra lançou nas definições e princípios dos primeiros artigos uma certa ousadia, retemperando com outros artigos, num sentido ambivalente. Dessa forma, o art. 17, "a" a "f", 121 que trata do acesso à propriedade rural, feito por meio de distribuição ou redistribuição da terra, considera que a desapropriação por interesse social é apenas uma das formas de execução, paralelamente à doação, à compra e venda, à arrecadação dos bens vagos, reversão à posse (vetado) do Poder Público de terras ocupadas e exploradas inadequadamente, e à herança, ou legado.

Por outro lado, o Estatuto da Terra estabeleceu, entre as cefinições dadas no art. $4^{\circ}$, itens I a IX,122 a de Empresa rural, no item VI, ${ }^{123}$ sem fazer referência à desapropriação por interesse social. No art. 19, § 3.0 "c"124 excetuando o caso de necessidade ou utilidade pública, considerou isentos de desapropriação.

Art. 19

$\S 3.0$

c) os imóveis que, embora não classificados como emprêsas rurais, situados fora da área prioritária da Reforma Agrária, tiverem aprovados pelo Instituto Brasileıro de Reforma Agrária, e em execução, projetos que, em prazo determinado, os elevem àquela categoria.

O Estatuto da Terra estabelece, ainda como parâmetros fundamentais, o zoneamento do país, sob o aspecto sócio-econômico, e a agilização fundiária, ressaltando as diversidades regionais, o estabelecimento do módulo de propriedade ajustado às característ:cas de cada zona, levando em consideração o tipo de exploração rural.

119) BRASIL, Estatuto da terra, art. 37-42, p. 23-5.

120) BRASIL, Estatuto da terra, art. 27-31 p. 21-2.

121) BRASIL, Estetuto da terra, art. 17, a-f, p. 18.

122) BRASIL, Estatuto da terra, art. $4 . \circ \mathrm{I} I \mathrm{I}$, p. 15-6.

123) BRASIL, Estatuto da terra, art. $4 . \circ \mathrm{VI}$, p. 15.

124) BRASIL, Estatuto da terra, art. $19, \S 3 .^{\circ}$ c, p. 18-9. 
Em síntese, o Estatuto da Terra regulamenta as terras públicas e particulares, aciona alguns mecanismos para se atingir a reforma agrária, dispõe sobre a dstribuição das terras, o financiamento, a execução e a administração da reforma agrária, bem como a política de desenvolvimento rural, incluindo a tributação da terra, a colonização, a assistência e proteção à economia rural e o uso, ou posse temporária da terra.

O Estado firmou a sua posição, não tornando ilegítima a propriedade minifundiária, mas procurando evitar, pe'o Estatuto da Terra, a sua subdivisão em áreas inferiores ao módulo e transmissão a terceiros.

A legislação de terras devolutas é complementada com outros decretos-leis e leis, assim o decreto n. ${ }^{\circ} 1414$, de 28 de agosto de $1975,{ }^{125}$ e a lei $n .^{\circ} 6383$, de 7 de dezembro de $1976,{ }^{126}$ que dispõe sobre o processo discriminatório de terras devolutas da União e dá outras providências.

No Paraná, a lei n. ${ }^{0} 7055$, de 4 de dezembro de 1978, ${ }^{127}$ dispõe sobre terras devolutas do Estado e dá outras providências, inclusive sobre o registro de posse e licença de ocupação em terras levolutas, discriminação em terras devolutas, ocupação, aproveitamento e plano de colonização das terras devolutas, legitimação das posses e outras.

O decreto estadual n..$^{\circ} 6414$, de 4 de dezembro de $1978,{ }^{128}$ regulamenta a lei n. ${ }^{0} 7055$, acima referida, e dá outras providências, prescrevendo toda a ação do Instituto de Terras e Cartografia do Estado do Paraná - ITC.

A lei estadual n. ${ }^{\circ} 7264$, de 10 de dezembro de $1979,{ }^{129}$ dispõe sobre a reserva em zonas urbanas, mediante escolha do ITC, $(*)$ de terrenos devolutos para obras públicas e dá outras providências.

A legislação renova-se, procurando atender e solucionar os problemas das terras devolutas, sendo decisiva a ação do Estado através dos seus orgãos competentes, estando em jogo os interesses de componentes das diversas comunidades brasileiras.

125) Decreto-lei n. 1414, de 18 de agosto de 1975. In: JUNQUEIRA, p. 133.

126) Lei $n . .^{\circ} 6383$, de 7 de dezembro de 1976 - Dispõe sobre o processo discriminatório de terras devolutas da União e dá outras providências. In: INSTITUTO DE TERRAS E CARTOGRAFIA. Terras devolutas, processo discriminatório; doutrina, legislação. Curitiba. s. d. p. 109-19.

127) Lei n. 7055, de 4 de dezembro de 1978. Dispõe sobre terras devolutas do Estado e dá outras providências. In: INSTITUTO DE TERRAS E CARTOGRAFIA, p. 71-83.

128) Decreto $n .^{\circ} 6414$, de 4 de dezembro de 1978 . Regulamenta a lei $n .^{\circ} 7055$, de 4 de dezembro de 1978 e dá outras providências. In: INSTITUTO DE TERRAS E CARTOGRAFIA, p. 85-90.

129) Lei estadual $n .{ }^{\circ} 7264$, de 10 de dezembro de 1979. In: INSTITUTO DE TERRAS E CARTOGRAFIA, p. 121-4.

- Atualmente Instituto de Terras, Cartografia e Florestas. 


\section{Conclusão}

Do exposto neste capítulo depreende-se que houve uma evolução na legislação de terras do Brasil, cuja origem prende-se à História do Direito Português, herança esta herdada com um conjunto de instituições políticas, sociais e econômicas.

As contingêncas históricas locais determinaram o surgimento de um Direito costumeiro, que foi norteando as relações nas estruturas sociais e agrárias, até se organizarem as Constituições e os Códigos e estabelecer-se um corpo de legislação voltada para a solução de problemas de terras no Brasil. Nessa tarefa foi decisivo o papel das elites pensantes, que deixaram transparecer os objetivos das lideranças do poder, forçando a elaboração de uma iegislação voltaủa para os seus próprios interesses, sem levar em conta os outros representantes da sociedade.

O instituto jurídico da sesmaria passou por uma transforma. ção e uma adaptação face à realidade brasileira, quer na extensão das áreas concedidas, quer no atendimento aos objetivos de povoamento e de cultura, constituindo sinal de distinção e símbolo do poder de uma elite aristocrática, senhorial latifundiária e escravocrata.

Se os primeiros representantes da intelligentsia brasileira buscaram formação universitária européia (Portugal, França, Inglaterra) e procuraram adaptar modelos estrangeiros, aos poucos foram se desenvolvendo valores culturais nacionais, habilmente impostos por uma classe privilegiada, representada, inicialmente pelos grandes senhores de terras e depois pelos barões do café e os industriais, até chegar aos tecnocratas dos dias atuais, decorrência do desenvolvimento do capitalismo brasileiro, ligado ao capitalismo mundial.

O Estado procurou estabelecer os fundamentos jurídicos para a solução do problema de terras, tanto nas Constituições como na legislação de terras, primeiramente de forma centralizada, na época do Império e, depois, descentralizada, com a implantação do federalismo republicano.

Foi necessário regulamentar a situação das terras devolutas por razões de Estado, que, inclusive, se via prejudicado nos seus interesses e alijado em seu poder, ficando a política agrária, em geral, à mercê da vontade das elites dominantes, que impunham a sua vontade, e dos posseiros, que se apossavam ilegalmente das terras.

A importância da Lei de Terras de 1850 e do seu Regulamento de 1854, implantando um novo sistema de obtenção da terra pela compra, transcende o momento histórico no qual foi forjada, desempenhando papel decisivo na solução de problemas de 
terras em geral, e, especialmente, de terras devolutas, servindo, inclusive, de inspiração para a legislação organizada pelos Estados, após a Proclamação da República.

O modelo da colonização, formulado por Edward Gibbon Wakefield, aplicado em alguns princípios da Lei de Terras, testado na prática, produziu alguns resultados positivos, quando parte da mão-de-obra estrangeira dedicou-se ao trabalho agrícola, à grande lavoura cafeeira, à construção de estradas e a atividades ligadas a certas indústrias, devido ao elevado preço de terras, para depois se tornar proprietária.

Por força da Lei de Terras, complementada com a legislação específica, foi institucionalizada a pequena propriedade e incentivada a vinda de contingentes de imigrantes.

Mesmo sendo elaborada por lideranças intelectuais, a Lei de Terras veio beneficiar contingente expressivo da população brasileira, representado por posseiros, legalizando a posse e transformando uma situação de fato em uma situação de direito, contribuindo para o estabelecimento do status juríd:co do posseiro.

O problema de terras faz parte de um processo de renovação muito mais amplo, que se deu nas instituições brasileiras nos séculos XIX e XX, acompanhado de transformações estruturais de ordem política, social, econômica e cultural.

Para que as mudanças implantadas nas Constituições e na legislação de terras não sejam apenas de ordem formal é preciso que haja participação, na sua elaboração e aplicação, pelas diversas camadas sociais, que aspiram, sobretudo, uma reforma agrária. Tudo é uma questão de direito e de defesa dos reais interesses do povo brasileiro, que vem lutando para conseguir, numa conquista gradual e paulatina, maior participação nos destinos do Brasil. 